Article

\title{
Assessing the Viability of Reintroduction of Locally Extinct Migratory Fish Brycon orbignyanus: Successful Growth, Dispersal and Maturation
}

\author{
Juan R. Esquivel-Muelbert ${ }^{1, *}$, Luisa Fontoura ${ }^{2}$, Éverton Zardo ${ }^{3}$, Danilo P. Streit, Jr. ${ }^{3}$, \\ Adriane Esquivel-Muelbert ${ }^{4}$ (i) and Juan R. E. Garcia ${ }^{1,5}$ \\ 1 Piscicultura Panamá, km 8 Estrada Geral do Bom Retiro, Paulo Lopes 88490-000, Santa Catarina, Brazil; \\ juan.esquivelgarcia@gmail.com \\ 2 Department of Environmental Sciences, Macquarie University, 12 Wally's Walk, Sydney 2109, \\ New South Wales, Australia; fontoura.luh@gmail.com \\ 3 Departamento de Zootecnia, Universidade Federal do Rio Grande do Sul, 7712 Avenida Bento Gonçalves, \\ Porto Alegre 91540-000, Rio Grande do Sul, Brazil; everton_zardo@hotmail.com (É.Z.); \\ danilo.streit@ufrgs.br (D.P.S.J.) \\ 4 School of Geography, University of Leeds, The School of Geography, Garstang North, Leeds LS72LL, UK; \\ adriane.esquivel@gmail.com \\ 5 Departamento de Medicina Veterinária, Universidade do Sul de Santa Catarina, 787 Avenida José Acácio \\ Moreira, Dehon, Tubarão 88704-900, Santa Catarina, Brazil \\ * Correspondence: juan.muelbert@gmail.com; Tel.: +61-0424-532-015
}

Received: 3 August 2018; Accepted: 26 September 2018; Published: 1 October 2018

\begin{abstract}
The reintroduction of threatened fish species in areas where wild populations have been depleted due to anthropogenic impacts is an increasingly popular conservation tool and mitigation policy. Despite the importance of fish reintroduction for conservation purposes, little is known about its efficiency. Here, we assessed the viability of reintroduction of the endangered migratory fish, Brycon orbignyanus, in an area of the Upper Uruguay River basin where the species has not been reported for more than 30 years. We released 4000 yearling juveniles in the Pelotas River in 2014 and maintained 400 juveniles in captivity as a control population. After three years, a total of 13 individuals was recaptured, of which, 10 were considered sexually mature with first maturation being recorded in animals larger than $42 \mathrm{~cm}$ in total body length. The age-length comparison with a control population growth curve showed that recaptured fish were slightly bigger than those in captivity. Furthermore, important ecological attributes as schooling behavior and dispersal capacity were recorded for all recaptured individuals. Combined, our results suggest that the re-establishment of a self-sustained population of locally extinct species B. orbignyanus in the Pelotas River may be successful if sustained over time and supported by conservation policies.
\end{abstract}

Keywords: conservation; endangered; fish; migratory; reintroduction

\section{Introduction}

Anthropogenic disturbances have largely contributed to the recent loss in biodiversity in aquatic ecosystems [1]. Habitat fragmentation and obstruction of migration routes due the construction of dams have led to the decline and local extinction of numerous fish species [2]. Attempts to recover depleted populations have been implemented worldwide [3] as species loss can affect the stability, resilience, and food web dynamics of aquatic ecosystems and also impact the welfare of human populations that depend on fisheries resources [4-6]. The reintroduction of captive-bred fishes in areas 
where wild populations have been extinguished has been commonly used as a fisheries management tool and for conservation purposes $[7,8]$.

In reintroduction programs, the establishment of self-sustaining populations in the wild is the principal aim for the long-term viability of fish stocks. The success of reintroduction programs depends on the size and health of released fish, behavioral changes due to domestication and characteristics of the release site as water quality and flow, food availability, and presence of predators [9]. Historically, stocking of endangered fish species into their former habitats have low success rates, often related to post-release mortality and wrong pre and post-release management strategies [2]. Therefore, survival to reproductive age is crucial to the establishment of self-sustaining populations in rivers affected by human activities [10].

In Brazil, all the major rivers are under the influence of dams, impoundments, and other human-related activities [11]. The Upper Uruguay River Basin, for example, has experienced a considerable change in land use since the first human settlement in 1620. As a consequence of unplanned economic development, the fish community suffered impacts from pollution, overfishing, deforestation, and most importantly, from the construction of in-stream barriers [12]. In the early 1980 's, the basin was highly contaminated by industrial and urban effluents, which had a great impact over the river's wildlife [13]. A large mobilization of the community and governmental authorities was able to improve the water quality, but did not restore fish populations [13]. In addition, the construction of a sequence of four hydroelectric dams in the Upper Uruguay River Basin blocked the reproductive migration routes of large migratory fishes, such as Brycon orbignyanus, Salminus brasiliensis and Pseudoplatystoma corruscans [14].

Brycon orbignyanus is a South American freshwater migratory species that inhabits the Uruguay, Paraná and Paraguay river basins, attaining a maximum weight of $10 \mathrm{~kg}$ and $800 \mathrm{~mm}$ of length [13]. This omnivorous fish is highly dependent on riverine forests and plays an important role in the dispersal of seeds [15], as its diet primarily consists of fruits, plants, and insects [12,16]. Pronounced schooling behavior observed in B. orbignyanus is an important ecological trait for its reproduction, which consequently makes the species more vulnerable to overfishing. Due to inadequate management of riverine areas, the species is federally listed as endangered and has practically disappeared from the Lower and Upper Uruguay basins [17]. Furthermore, the species remained absent from surveys conducted in Upper Uruguay from 1986 to 2000 and has not been reported by local fishermen associations since 1980 [12].

Effective reintroduction programs and management actions focused on the re-establishment of fish populations could revert the current status of B. orbignyanus in areas where the species is considered functionally extinct. In this study, a reintroduction experiment was implemented in an attempt to assess the survival, dispersal, and growth of captive-bred juveniles of B. orbignyanus stocked in the Pelotas River to support the development of a long-term reintroduction program. The results of this research have implications for other conservation programs of endangered migratory fish species that use reintroduction as a tool for recovering locally extinct populations.

\section{Results}

We recaptured 13 fish in the Pelotas River on 5 occasions during 2016 and 2017. Schooling behavior was observed on 3 occasions with up to 5 fish recaptured at the same time. Additionally, downstream dispersal was registered for all individuals and the range of recapture was between 36 and $80 \mathrm{~km}$ from the release site (Figure 1).

Individuals varied from 377 to $492 \mathrm{~mm}$ in total length and from and from 776 to $1600 \mathrm{~g}$ in total weight (detailed information on Table S1 in the Supplementary Material). Despite the presence of gonads in all the 13 fish, only 10 were considered sexually mature with first maturation being recorded in animals larger than $42 \mathrm{~cm}$. (Figure 2). Genetic analysis showed that molecular variance between recaptured and control population was considered low for B. orbignyanus, with a significant pairwise Fixation index (Fst $=0.108, p<0.001$ ) [18] (detailed information on Tables S2-S4 in the Supplementary Material). 


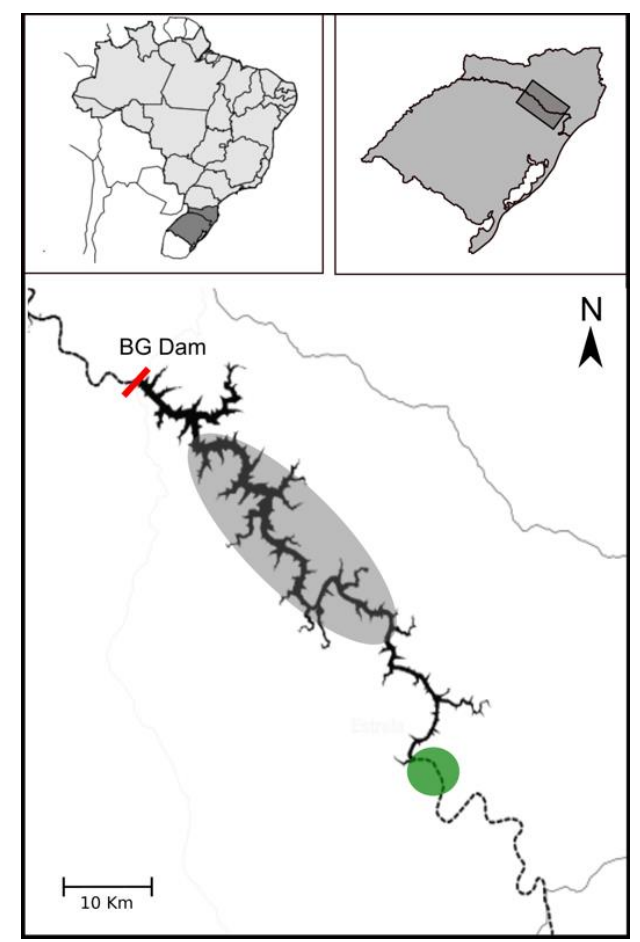

Figure 1. Map of the study area. Barra Grande Dam is represented by the red line. Fish release site and recapture area are outlined in green and grey respectively.

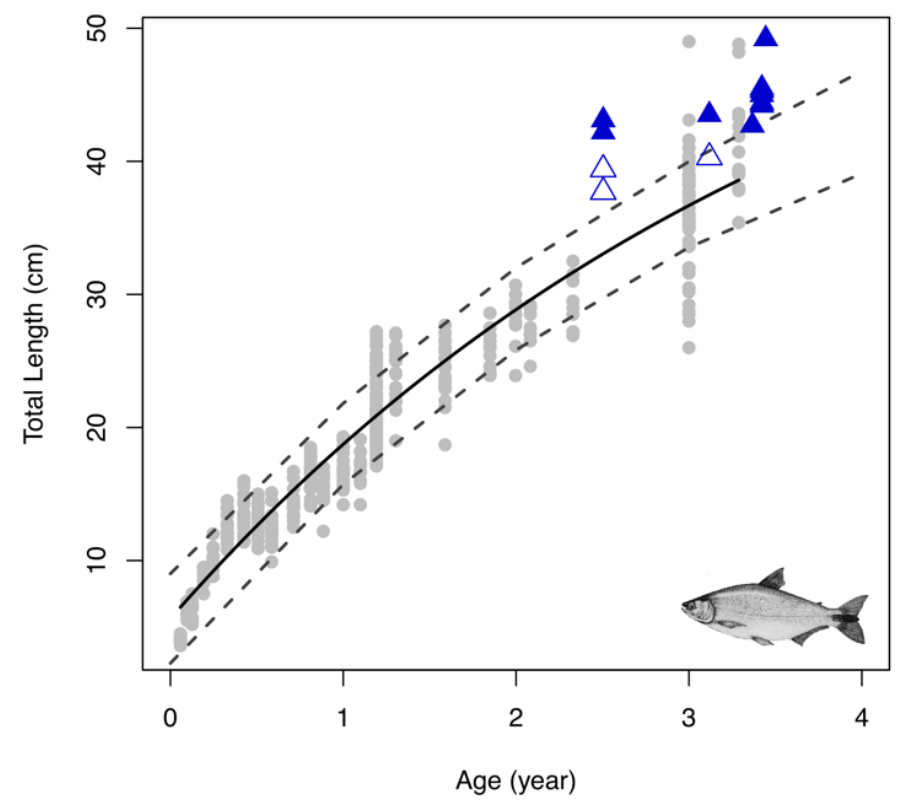

Figure 2. Comparison of the growth curve from Brycon orbignyanus control population and the age-length relationship of recaptured individuals (blue triangles; mature individuals are represented by color filled triangles). Confidence intervals of growth model are represented by dotted lines and grey points represent age-length individuals from the control population.

Comparisons between the age-length relationship of recaptured fish and the growth model from control population indicated that the growth rates of recaptured individuals were significantly higher than expected by the growth curve the control population (Figure 2). Parameter estimates and 95\% confidence interval of fitted growth model from control population are described in Table 1. 
Table 1. Parameter estimates and predicted lower (L95\%) and upper (U95\%) confidence intervals of fitted von Bertalanffy growth model from the control population. $L \infty$ is the asymptotic average length; $K$ the annual growth, and $t 0$ the theoretical age at zero length

\begin{tabular}{cccc}
\hline Parameter & Estimated & L95\% & U95\% \\
\hline$L \infty$ & 59 & 56.04 & 74.56 \\
$K$ & 0.3 & 0.199 & 0.316 \\
$t 0$ & -0.36 & -0.46 & -0.29 \\
\hline
\end{tabular}

\section{Discussion}

We have assessed the viability of reintroduction of a locally extinct species, Brycon orbignyanus, in the Pelotas River by determining whether released fish were capable to survive, disperse, and grow in the study area. Our results suggest that the habitat provided enough resources for reintroduced fish to survive and grow to reproductive age. The age-length comparison with the control population showed that recaptured fish were slightly bigger than the captive animals and indicated a good potential for the recovery of a population of B. orbignyanus in the area. Furthermore, reintroduced individuals demonstrated the capacity to form schools and to disperse along the river that indicates the conservation of important life-history traits for the species.

We observed relatively low levels of molecular variance between the recaptured and control populations, indicating similarities between them [18]. However, the genetic data available unable us to conclude whether control and recaptured individuals derived from the same founders, as there is, to some extent, genetic differences between the two study groups. We understand that the observed levels of genetic variation between groups are a consequence of the composition of the parental population that was sourced across an area of approximately $300 \mathrm{~km}$ of the same river basin over a period of 10 years. Such genetic diversity was intentional when selecting the released group, as genetic variation can contribute to the success of reintroduction programs by enabling the species to better respond to natural selection and adapt to their new environment [19]. Future studies should aim for exact similar parental populations for released and control populations. By doing so, one could potentially understand which genotypes are most likely to be successfully reintroduced.

Several studies have demonstrated the importance of post-release survival, dispersal, and growth to reproductive age $[8,9,19-21]$ for the success of reintroduction programs and that post-release mortality has a large impact over the initial population size [22]. It is considered for larger juveniles to have higher chances of surviving when released into the wild $[23,24]$, and thus, the release of yearling juveniles was considered appropriate for the purpose of this experiment. While we could not estimate survival rates, our data shows that reintroduced fish were capable to survive for more than three years to reach sexual maturity.

Brycon orbignyanus has late sexual development compared to other freshwater fish species, with maturation starting between the second and third year of life with at least $30 \mathrm{~cm}$ of body length [25]. However, the estimated size of the first maturity where $100 \%$ of the individuals of the species are sexually mature (Lm100) is around $42 \mathrm{~cm}$. In our study, the length of sexually mature individuals varied between 42 and $49 \mathrm{~cm}$. As a large migratory fish, the species is known to migrate downstream for reproduction in the lower Paraná and Uruguay rivers, during December and January each year [26]. However, the opposite migration pattern occurs in the upper Paraná River, where the reproductive migration occurs upstream [15]. This different migratory behavior between populations suggests that the reintroduced animals might be able to reproduce using the stretch of free-flowing river upstream the Barra Grande Dam.

Long-term monitoring is an important component of successful reintroduction programs [3]. While our reports of survival and dispersal indicate the preliminary success of this experiment, the number of recaptured individuals were small when compared to the total number of stocked animals, but considering the large area of study and the relatively small effort put in to this experiment, we believe that is likely that a larger group of individuals will be inhabiting the area. Environmental 
and biological variables have important impacts on reintroduction outcomes [10] and given this, we can conclude that a bigger stocking effort is needed in order to establish a self-sustaining population. Studies of population modeling for the reintroduction of endangered fishes suggest that long-term (5-10 years) stocking strategies are more likely to succeed by increasing the chances of the stocked cohort encountering favorable environmental conditions $[8,27,28]$

Addressing the cause of a population's initial decline is also crucial for the reestablishment of locally extinct populations and the long-term success of a reintroduction program [3]. In the Upper Uruguay River, physical barriers to migration, deforestation, and overfishing led to the decline of the species [12,13]. We highlight the importance of the establishment of protected areas in the Upper Uruguay River Basin alongside with improving the enforcement of fisheries regulations in order to reduce the impact of the fishing activity over large migratory species. Our study indicates that threatened large-bodied migratory fishes can be successfully reintroduced in rivers affected by human activities if supported by a group of interconnected management practices.

\section{Materials and Methods}

\subsection{Study Area}

The study was conducted in the Pelotas River, the main headstream of the Upper Uruguay river basin. The river rises in the highlands of Santa Catarina State in Brazil and flows Northeast for $450 \mathrm{~km}$ until meeting the Canoas River forming the Uruguay River. The rocky terrain and the topography of the watershed result in sudden variations in flow [12]. Juveniles of Brycon orbignyanus were released in an area located $90 \mathrm{~km}$ upstream from the Barra Grande dam, the highest hydropower dam in a sequence of 4 dams in the upper Uruguay Basin (Figure 1).

\subsection{Source of Fish}

The population used to establish the restocking program was obtained from the remaining areas where the species is still present in the Upper Uruguay River basin and kept in captive at the Piscicultura Panama Aquaculture station. We utilized the hormone-induced reproduction technique described by Woynarovich and Horváth (1983) for warm-water freshwater fish species. [29]. The reproduction protocol aimed to maximize the genetic diversity following the guidelines described for B. orbignyanus [30], which included maintaining a sex ratio of 1:1 in spawned broodstock with single-pair mating and mixing offspring from all matings together before release.

The rearing protocol focused on providing life-skill training for juveniles to increase post-release survival rates [10]. Initially, larvae were fed using live bait in the hatchery and then transferred to fertilized earthen ponds under semi-natural conditions and fed with an artificial extruded diet. Fish were reared for one year alongside with other native species to stimulate behavioral learning [31].

\subsection{Release and Post-Release Monitoring}

The location and season for the release were established following the recommendations set out by the IUCN guideline for reintroduction programs [32]. We chose to release the juveniles during spring because historically the resources to ensure feeding are more abundant during spring and summer in the region. The presences of marginal forests, prey and predators as well as the influence of human activities and access for vehicles were taken into account. In November 2014, 4000 yearling juveniles were released. We used a soft-release approach, with $90 \mathrm{~min}$ of pre-release acclimatization, in order to improve the post-release survivorship [33].

We conducted two surveys per year for 3 years, in four sites in the study area using nine $30 \mathrm{~m}$ gillnets with $1.5 \mathrm{~m}$ of height and mesh sizes between $1.2 \mathrm{~cm}$ and $100 \mathrm{~cm}$ opposites knots. In addition to our systematic monitoring, the fishermen association was responsible for a greater fishing effort, with 35 registered fishermen fishing on average 2 days per month with $50 \mathrm{~m}$ gillnets with $1.5 \mathrm{~m}$ of height 
and mesh sizes between $50 \mathrm{~cm}$ and $120 \mathrm{~cm}$ opposites knots. The nets were set for twelve hours per day at every location.

Captured fish were measured, weighted and eviscerated for gonadal removal. Sexual maturity was visually classified by gonad examination following Vazzoler (1981) [34]: Stage I (immature); gonads of reduced size, translucent, located adjacent to the vertebral column, stage II (maturing); gonads occupying a third of the abdominal cavity with well-developed capillary network; stage III (mature); gonads turgid, occupying the majority of the abdominal cavity; and stage IV (empty or resting) gonads flaccid with hemorrhagic aspect. For the propose of this study, we considered fish as immature when gonads were classified as stage I and mature when gonads classified as stages II to IV. We compared the results of the gonadal analysis with the estimated size of the first maturity for the species where $100 \%$ of the individuals are sexually mature (Lm100) [35].

\subsection{Control Population}

In order to enable a comparison with the reintroduced fish four hundred juveniles were randomly selected and kept in captivity in low densities $\left(1\right.$ individual $\left.\mathrm{m}^{-2}\right)$ [36] forming the control population. Weight $(\mathrm{g})$ and length $(\mathrm{cm})$ of the control population were monitored during a period of 1200 days. The collected data were used to create a growth curve and compare the growth of the control population with the reintroduced animals.

\subsection{Genetics}

We conducted analysis to investigate genetic variance between recaptured fish and control population. We extracted and purified DNA from caudal fin tissue collected from 13 B. orbignyanus caught from the Pelotas River and 26 individuals from the control population kept in captivity. Total genomic DNA was extracted using the modified salt $(\mathrm{NaCl})$ extraction protocol [37]. We investigated the genotype of the 39 individuals using nine microsatellite loci [38]. Genetic population structure was quantified by analysis of molecular variance (AMOVA) [39]. The pairwise Fixation index (Fst) was used to estimate the genetic differentiation between populations of recaptured and captive fish. All genetic analyses were conducted using the software GenAlEx 6,5 [40].

\subsection{Growth Model}

To compare the fish growth of recaptured and captive individuals, we fitted a von Bertalanffy growth model [41] for control population:

$$
L t=L \infty \times\left(1-e^{-k(t-t 0)}\right) .
$$

where $L t$ is the average length expected at time $t ; L \infty$ is the asymptotic average length; $K$ the annual growth, and $t 0$ the theoretical age at zero length. To estimate the initial values of $L \infty$ and $t 0$, we applied the vbStarts function. Subsequently, to fit a von Bertalanffy growth curve for the control population we applied a non-linear least squares regression using the nls function. Finally, we assessed the position of the recaptured individuals in relation to the growth curve from the control population. The analysis was performed in R [42] using the fisheries stock-assessment method package (FSA) for R [43].

\subsection{Regulatory and Ethical Compliance}

This study was performed under the authorization 93/2012 from the Brazilian Institute of Environment and Renewable Natural Resources-IBAMA, with the approval of the Ethical Committee on Animal Experiments (permit 171.2012.50 CEUA/UEL).

\section{Conclusions}

In this study, we observed that reintroduced juveniles of $B$. orbignyanus were able to reach the size of first maturation and conserved important life history traits for the species (e.g., dispersion 
capacity, schooling behavior). These results suggest that the re-establishment of the species in the area of study might be possible [3]. However, a long-term monitoring program will be required to identify changes in population trajectory and assess if reintroduced fish will be able to reproduce and establish a self-sustained population [8-10] in the Pelotas River. Additionally, we suggest that strategic planning has to be applied in the basin scale when dealing with migratory species with large home ranges.

Supplementary Materials: The following are available online at http:/ / www.mdpi.com/2410-3888/3/4/39/s1, Table S1: Details of the recaptured fish, Table S2: Characteristics of the amplified microsatellite loci, Table S3. Intra-population genetic diversity indexes obtained for two groups of Brycon orbignyanus. Average values based on 5 microsatellite loci, Table S4. Analysis of Molecular Variance (AMOVA) for recaptured and captive Brycon orbignyanus based on microsatellite markers.

Author Contributions: Conceptualization, J.R.E.-M., L.F., A.E.-M. and J.R.E.G.; data curation, J.R.E.-M., L.F. and É.Z.; formal analysis, É.Z.; funding acquisition, J.R.E.G.; methodology, L.F. and A.E.-M.; project administration, J.R.E.G.; resources, J.E.-M. and D.P.S.J.; supervision, D.P.S.J. and J.R.E.G.; writing original draft, J.R.E.-M.; writing review \& editing, L.F., D.P.S.J., A.E.-M. and J.R.E.G.

Funding: This research was funded by Barra Grande Energética S.A-BAESA.

Acknowledgments: We thank J. Manuzzi for supporting the elaboration and execution of this project and M. Martinez, A. de Souza, A. Salmória and J. Salmória for sample collection.

Conflicts of Interest: The authors declare no conflict of interest. The funders had no role in the design of the study; in the collection, analyses, or interpretation of data; in the writing of the manuscript, and in the decision to publish the results.

\section{References}

1. Liermann, C.R.; Nilsson, C.; Robertson, J.; Ng, R.Y. Implications of Dam Obstruction for Global Freshwater Fish Diversity. Bioscience 2012, 62, 539-548. [CrossRef]

2. Agostinho, A.A.; Gomes, L.C.; Pelicice, F.M. Ecologia e Manejo Recursos Pesqueiros em Reservatórios do Brasil; EDUEM: Maringá, Brazil, 2007; pp. 253-274.

3. Cochran-Biederman, J.L.; Wyman, K.E.; French, W.E.; Loppnow, G.L. Identifying Correlates of Success and Failure of Native Freshwater Fish Reintroductions. Conserv. Biol. 2015, 29, 175-186. [CrossRef] [PubMed]

4. Holmlund, C.M.; Hammer, M. Ecosystem Services Generated by Fish Populations. Ecol. Econ. 1999, 29, 253-268. [CrossRef]

5. Petchey, O.L.; Gaston, K.J.; Building, A.D.; Bank, W.; Sheffield, S. Extinction and the Loss of Functional Diversity. Proc. R. Soc. Lond. B Biol. Sci. 2002, 269, 1-7. [CrossRef] [PubMed]

6. Winemiller, K.O.; McIntyre, P.B.; Castello, L.; Fluet-Chouinard, E.; Giarrizzo, T.; Nam, S.; Baird, I.G.; Darwall, W.; Lujan, N.K.; Harrison, I.; et al. Balancing Hydropower and Biodiversity in the Amazon, Congo, and Mekong. Science 2016, 351, 128-129. [CrossRef] [PubMed]

7. Molony, B.W.; Lenanton, R.; Jackson, G.; Norriss, J. Stock Enhancement as a Fisheries Management Tool. Rev. Fish Biol. Fish. 2005, 13, 409-432. [CrossRef]

8. Lyon, J.P.; Todd, C.; Nicol, S.J.; MacDonald, A.; Stoessel, D.; Ingram, B.A.; Barker, R.J.; Bradshaw, C.J.A. Reintroduction Success of Threatened Australian Trout Cod (Maccullochella macquariensis) Based on Growth and Reproduction. Mar. Freshw. Res. 2012, 63, 598-605. [CrossRef]

9. Ebner, B.C.; Thiem, J.D. Monitoring by Telemetry Reveals Differences in Movement and Survival Following Hatchery or Wild Rearing of an Endangered Fish. Mar. Freshw. Res. 2009, 60, 45-57. [CrossRef]

10. Brown, C.; Day, R.L. The Future of Stock Enhancements: Lessons for Hatchery Practice from Conservation Biology. Fish Fish. 2002, 3, 79-94. [CrossRef]

11. Pelicice, F.M.; Azevedo-Santos, V.M.; Vitule, J.R.S.; Orsi, M.L.; Lima Junior, D.P.; Magalhães, A.L.B.; Pompeu, P.S.; Petrere, M.; Agostinho, A.A. Neotropical Freshwater Fishes Imperilled by Unsustainable Policies. Fish Fish. 2017, 18, 1119-1133. [CrossRef]

12. Zaniboni-Filho, E.; Schulz, U.H. Migratory fishes of the Uruguay River. In Migratory Fishes of South America: Biology, Fisheries and Conservation Status; Carosfeld, J., Harvey, B., Ross, C.V., Baer, A., Eds.; The World Bank, International Development Centre: Ottowa, ON, Canada, 2003; pp. 157-194.

13. De Godoy, M.P. Peixes Do Estado de Santa Catarina; Universidade Federal de Santa Catarina: Florianópolis, SC, USA, 1987. 
14. Schork, G.; Hermes-Silva, S.; Zaniboni-Filho, E. Analysis of Fishing Activity in the Itá Reservoir, Upper Uruguay River, in the Period 2004-2009. Braz. J. Biol. 2013, 73, 559-571. [CrossRef] [PubMed]

15. Costa-Pereira, R.; Galetti, M. Frugivore Downsizing and the Collapse of Seed Dispersal by Fish. Biol. Conserv. 2015, 191, 809-811. [CrossRef]

16. Agostinho, A.; Gomes, L.; Suzuki, H.; Julio, H. Migratory Fishes of the Upper Paraná River Basin, Brazil. In Migratory Fishes of South America: Biology, Fisheries and Conservation Status; Carosfeld, J., Harvey, B., Ross, C.V., Baer, A., Eds.; The World Bank, International Development Centre: Ottowa, ON, Canada, 2003; pp. 19-98.

17. De Oliveira, D.J.; Ashikaga, F.Y.; Foresti, F.; Senhorini, J.A. Conservation Status of the "Piracanjuba" Brycon orbignyanus (Valenciennes, 1850) (Characiformes, Bryconidae): Basis for Management Programs. Biodivers. Bras. 2017, 7, 18-33.

18. Ashikaga, F.Y.; Orsi, M.L.; Oliveira, C.; Senhorini, J.A.; Foresti, F. The endangered species Brycon orbignyanus: Genetic analysis and definition of priority areas for conservation. Environ. Biol. Fish. 2015, 98, 1845-1855. [CrossRef]

19. Brown, G.E.; Smith, R.J.F. Acquired Predator Recognition in Juvenili Rainbow Trot (Oncorhynchus mykiss): Conditioning Hatchery-Reared Fish to Recognize Chemical Cues of a Predator. Can. J. Fish. Aquat. Sci. 1998, 55, 611-617. [CrossRef]

20. Todd, C.R.; Lintermans, M. Who Do You Move? A Stochastic Population Model to Guide Translocation Strategies for an Endangered Freshwater Fish in South-Eastern Australia. Ecol. Model. 2015, 311, 63-72. [CrossRef]

21. Zhang, L.; Jiang, W.; Wang, Q.J.; Zhao, H.; Zhang, H.X.; Marcec, R.M.; Willard, S.T.; Kouba, A.J. Reintroduction and Post-Release Survival of a Living Fossil: The Chinese Giant Salamander. PLoS ONE 2016, 11, 1-15. [CrossRef] [PubMed]

22. Armstrong, D.P.; Seddon, P.J. Directions in Reintroduction Biology. Trends Ecol. Evol. 2008, 23, $20-25$. [CrossRef] [PubMed]

23. Masuda, R.; Tsukamoto, K. Stock Enhancement in Japan: Review and Perpective. Bull. Mar. Sci. 1998, 62, 337-358.

24. Svåsand, T.; Kristiansen, T.S.; Pedersen, T.; Salvanes, A.G.V.; Engelsen, R.; Naevdal, G.; Nødtvedt, M. The Enhancement of Cod Stocks. Fish Fish. 2000, 1, 173-205. [CrossRef]

25. Vazzoler, A.E.; Suzuki, H.I.; Marques, E.E.; Lizama, M.D. Primeira Maturação Gonadal, Periodos E Areas de Reprodução. In A Planície de Inundação do alto Rio Paraná-Aspectos Físicos, Biológicos e Socioeconômicos; Vazzoler, A.D., Agostinho, A.A., Hahn, N.S., Eds.; EDUEM: Maringá, Brazil, 1997; pp. $249-265$.

26. Ringuelet, R.A.; Arámburu, R.H.; Alonso de Arámburu, A.S. Los Peces Argentinos de Agua Dulce; Dirección de Conservación de la Fauna de la Provincia de Buenos Aires: Buenos Aires, Argentina, 1967.

27. Bearlin, A.R.; Schreiber, E.S.; Nicol, S.J.; Starfield, A.M.; Todd, C.R. Identifying the Weakest Link: Simulating Adaptive Management of the Reintroduction of a Threatened Fish. Can. J. Fish. Aquat. Sci. 2002, 59, 1709-1716. [CrossRef]

28. Todd, C.R.; Nicol, S.J.; Koehn, J.D. Density-Dependence Uncertainty in Population Models for the Conservation Management of Trout Cod, Maccullochella macquariensis. Ecol. Model. 2004, 171, 359-380. [CrossRef]

29. Woynarovich, E.; Horváth, L. The Artificial Propagation of Warm-Water Finfishes: A Manual for Extension; Food and Agriculture Organization of the United Nations: Rome, Italy, 1980.

30. Lopera-Barrero, N.M. Conservation of Brycon Orbignyanus Natural Populations and Stocks for Their Reproductive, Genetic, Environmental Sustainability: A Model for Species Threatened with Extinction. Ciencia e Investigación Agraria 2009, 36, 191-208. [CrossRef]

31. Wallace, M.P. Retaining natural behaviour in captivity for reintroduction programmes. In Behaviour and Conservation; Gosling, L.M., Sutherland, W.J., Eds.; Cambridge University Press: Cambridge, UK, 2000; pp. 300-314.

32. IUCN/SSC. Guidelines for Reintroductions and Other Conservation Translocations; Version 1.0; IUCN/SSC: Gland, Switzerland, 2013.

33. Olla, B.L. Behavioural Deficits in Hatchery-Reared Fish: Potential Effects on Survival Following Release. Aquac. Fish. Manag. 1994, 25, 19-34. 
34. Vazzoler, A.E.A.D.M. Manual de Métodos Para Estudos Biológicos de Populaçoes de Peixes: Reproduçao E Crescimento; CNPq: Brasília, Brazil, 1981.

35. Vazzoler, A.E.A.D.M. Biologia Da Reprodução de Peixes Teleósteos: Teoria E Prática; EDUEM: Maringá, Brazil, 1996.

36. Tolussi, C.E.; Wagner, A.; Hilsdorf, S.; Caneppele, D.; Guimarães Moreira, R. The Effects of Stocking Density in Physiological Parameters and Growth of the Endangered Teleost Species Piabanha, Brycon insignis (Steindachner, 1877). Aquaculture 2010, 310, 221-228. [CrossRef]

37. Lopera-Barrero, N.M.; Povh, J.A.; Ribeiro, R.P.; Gomes, P.C.; Jacometo, C.B.; Silva Lopes, T.D. Comparación de Protocolos de Extracción de ADN Con Muestras de Aleta Y Larva de Peces: Extracción Modificada Con Cloruro de Sodio. Ciencia e Investigación Agraria 2008, 35, 77-86. [CrossRef]

38. Barroso, R.M.; Hilsdorf, A.W.S.; Moreira, H.L.M.; Mello, A.M.; Guimaraes, S.E.F.; Cabello, P.H.; Traub-Cseko, Y.M. Identification and Characterization of Microsatellites Loci in Brycon opalinus (Cuvier, 1819) (Characiforme, Characidae, Bryconiae). Mol. Ecol. Notes 2003, 3, 297-298. [CrossRef]

39. Excoffier, L.; Smouse, P.E.; Quattro, J.M. Analysis of molecular variance inferred from metric distances among DNA haplotypes: Application to human mitochondrial DNA restriction data. Genetics 1992, 131, 479-491. [PubMed]

40. Peakall, R.; Smouse, P.E. GenAlEx 6.5: Genetic Analysis in Excel. Population Genetic Software for Teaching and Research-An Update. Bioinformatics 2012, 28, 2537-2539. [CrossRef] [PubMed]

41. Von Bertalanffy, L. A quantitative theory of organic growth (inquiries on growth laws. II). Hum. Biol. 1938, 10, 181-213.

42. R Core Team. R: A Language and Environment for Statistical Computing; R Foundation for Statistical Computing: Vienna, Austria, 2017.

43. Ogle, D.H. FSA: Fisheries Stock Assessment Methods; R Package FSA Version 0.8.20; R Package: Madison, WI, USA, 2018.

(C) 2018 by the authors. Licensee MDPI, Basel, Switzerland. This article is an open access article distributed under the terms and conditions of the Creative Commons Attribution (CC BY) license (http:/ / creativecommons.org/licenses/by/4.0/). 